\title{
Amino acid composition of some fish products and casein
}

\author{
By GABRIELLE M. ELLINGER AND ELIZABETH B. BOYNE \\ Rowett Research Institute, Bucksburn, Aberdeen \\ (Received 21 May 1965-Accepted 19 Fuly 1965)
}

It has been shown that when vacuum-dried cod muscle is heated under controlled conditions of temperature and moisture the value of the protein as a supplement to cereal proteins diminishes (Carpenter, Ellinger, Munro \& Rolfe, 1957). After heat treatment of the cod muscle, lysine was found to be the limiting amino acid in the gross protein value (GPV; Heiman, Carver \& Cook, 1939) chick test and quality could be related to the available lysine content of the material. Yet, the supplementation of heated cod muscle with free lysine did not raise the GPV to the level obtained with the unheated cod muscle. Analyses were carried out to determine whether damage by heat treatment was reflected in the amino acid composition of acid hydrolysates prepared from heated cod muscle. Analyses are also reported for two other protein concentrates. Casein was chosen as the standard used in the GPV determinations and for comparison with other analyses in the literature. A sample of white-fish meal of known history and GPV was chosen as a protein used as standard in practical feeding trials, and for comparison with the cod-muscle preparations.

\section{EXPERIMENTAL}

\section{Materials}

The two cod fillets and the white-fish meal were the materials described in a previous publication (Carpenter et al. 1957) as meals D, E and H.

Vacuum-dried fillets D were prepared from cod muscle (Gadus callarias L.) freed from skin and bones. During drying under reduced pressure the maximum temperature within the fish was $60^{\circ}$, and storage was under nitrogen at $-5^{\circ}$.

Heated fillets $\mathrm{E}$ were prepared from $\mathrm{D}$ by raising the moisture content to approximately $\mathrm{I} .5 \%$, repacking in nitrogen and heating at $105^{\circ}$ for $36 \mathrm{~h}$. The product was stored at $-5^{\circ}$.

White-fish meal $\mathrm{H}$ was prepared from fresh cod offals only. After preliminary drying in a batch vacuum steam-drier, the highest temperature reached in a 'continuous' steam-drier at atmospheric pressure was $93^{\circ}$.

The sample of casein came from a commercial batch of Glaxo Casein C (Glaxo Research Ltd), described as Lactic Casein unextracted, which had been used as the standard protein in the determination of GPV of the above meals (Carpenter et al. 1957). Several batches of this casein, purchased over a period of years, had been found to be of constant quality in this test. 


\section{Methods}

Preparation of hydrolysates. Samples containing about $8 \mathrm{mg}$ nitrogen were refluxed with $200 \mathrm{ml}$ constant-boiling glass-distilled hydrochloric acid for $24 \mathrm{~h}$ by the method described by Schram, Dustin, Moore \& Bigwood (1953). Insoluble residues were filtered off on sintered glass and the hydrolysate was taken down to dryness in a rotary evaporator without raising the temperature above $5^{\circ}$. The sample was dissolved in $\mathrm{O} \cdot \mathrm{I} \mathrm{N}$-hydrochloric acid, made up to $\mathrm{IO} \mathrm{ml}$, centrifuged to separate insoluble material and stored at $+4^{\circ}$. Four hydrolysates were prepared from each material.

Chromatographic separation of amino acids. The revised method of Moore, Spackman \& Stein (1958) was used for the separation of amino acids present in the hydrolysate. Acidic and neutral acids were resolved on a $100 \mathrm{~cm}$ column of Amberlite CG I 20 Type II (Rohm \& Haas Co., Philadelphia). Only the 'through-200 mesh' fraction in the wet $\mathrm{Na}^{+}$form was used. Hydrolysate $(0.5 \mathrm{ml})$, mixed with an equal volume of double-strength buffer, was adjusted to $\mathrm{pH} 2 \cdot 0-2 \cdot 5$ before transfer to the column.

The basic amino acids were separated on a $15 \mathrm{~cm}$ column of the same resin; but only 'through-300 mesh' fraction was used in order to sharpen the separation between histidine and ammonia. At $50^{\circ}$, a 0.35 N-citrate buffer at $\mathrm{pH} 5.28$ was used for elution. I $\mathrm{ml}$ fractions were collected from both columns.

All buffers were made up in thymol water containing $0.25 \mathrm{~g}$ thymol/1. (Eastoe, 1955).

Colorimetric estimation of amino acids. The modified ninhydrin colour reaction of Moore \& Stein (1954) was employed using $0.5 \mathrm{ml}$ reagent with I $\mathrm{ml}$ fractions. Colour factors were found to agree closely with those given by the authors of the method except for phenylalanine, for which a colour factor of 9I was used. Readings of colour density were taken on a Unicam SP 600 spectrophotometer transferring fractions to a $\mathrm{r} \cdot \mathrm{O} \mathrm{cm}$ cell. Dilution for reading above $\mathrm{I} \cdot \mathrm{O}$ was avoided; instead cells with an optical path of $0.5 \mathrm{~cm}$ or even $0.2 \mathrm{~cm}$ were used.

Cystine. The method of Schram, Moore \& Bigwood (1954) was adopted for the estimation of cystine. Special care was taken to avoid complete drying of the oxidation mixture or delay before acid hydrolysis of this mixture. It was found that Amberlite CG 400 Type II may replace Dowex 2-Xro for this analysis (Dow Chemical Co., Midland, Michigan).

Total nitrogen. This was estimated by a macro-Kjeldahl method with mercuric oxide as catalyst (Association of Official Agricultural Chemists, 1950).

Hydroxyproline. This was estimated by the method of Neuman \& Logan (1950).

Ash. Samples were heated to constant weight at $55^{\circ}$.

\section{RESULTS}

Results of the analyses are presented in Table I. Amino acid concentrations are given in $\mathrm{g} / \mathrm{x} 6 \mathrm{~g}$ nitrogen as determined by the Kjeldahl analysis for the products concerned. They are each the means of single analyses on four hydrolysates unless otherwise stated, and they are given together with the estimate of the standard deviation of a single determination. For the means themselves the standard error 
would be one-half of the values shown. No corrections have been applied to compensate for any postulated losses of amino acids during hydrolysis. Cystine was completely destroyed during the standard hydrolysis. It has been assumed that consequently an equivalent amount of nitrogen appeared as ammonia. Cystine nitrogen was recorded a second time as cysteic acid in the hydrolysate prepared after oxidation.

Table I. The amino acid composition $(\mathrm{g} / \mathrm{1} 6 \mathrm{~g} N)$ of hydrolysates prepared from cod fillets, heated cod fillets, white-fish meal and casein

(Mean value with standard deviationt of four estimations unless otherwise shown by a figure in parentheses)

\begin{tabular}{|c|c|c|c|c|c|}
\hline & $\begin{array}{l}\text { Cod fillets } \\
\text { (control) } \\
\text { (I) }\end{array}$ & $\begin{array}{l}\text { Cod fillets } \\
\text { (heated) } \\
(2)\end{array}$ & $\begin{array}{l}\text { White-fish } \\
\text { meal } \\
\text { (3) }\end{array}$ & $\begin{array}{l}\text { Casein } \\
(4)\end{array}$ & $\begin{array}{l}\text { ificance } \\
\text { ifference } \\
(\mathrm{I}) \text { and (2 }\end{array}$ \\
\hline Taurine & $0.88 \pm 0.02$ & $0.77 \pm 0.01(2)$ & $0.80 \pm 0.04$ & 一 & $* * *$ \\
\hline Aspartic acid & $10.06 \pm 0.20$ & $9.77 \pm 0.18$ & $8.54 \pm 0.16$ & $7.66 \pm 0.14$ & - \\
\hline Threonine & $4.07 \pm 0.10$ & $3.96 \pm 0.16$ & $3.82 \pm 0.08$ & $4.3^{8} \pm 0.20$ & - \\
\hline Serine & $4.11 \pm 0.08$ & $3.76 \pm 0.08$ & $4.94 \pm 0.08$ & $5.90 \pm 0.12$ & $* *$ \\
\hline Glutamic acid & $15.25 \pm 0.34$ & $15.72 \pm 0.26$ & I $3.44 \pm 0.16$ & $23.55 \pm 0.20$ & - \\
\hline Proline & $3.40 \pm 0.24$ & $3.26 \pm 0.04$ & $6.47 \pm 0.18$ & $11 \cdot 70 \pm 0.26$ & 一 \\
\hline Glycine & $4.81 \pm 0.24$ & $4.89 \pm 0.10$ & $12.13 \pm 0.18$ & $2 \cdot 16 \pm 0.06$ & 一 \\
\hline Alanine & $6 \cdot 16 \pm 0.26$ & $6.5^{8} \pm 0.10$ & $7.32 \pm 0.12$ & $3.54 \pm 0.14$ & * \\
\hline Valine & $5.54 \pm 0.22$ & $6.06 \pm 0.06$ & $4.56 \pm 0.28(3)$ & $7 \cdot 38 \pm 0.08$ & - \\
\hline Methionine & $3.34 \pm 0.06$ & $3.54 \pm 0.18$ & $2.99 \pm 0.14$ & $3 \cdot 33 \pm 0.14(3)$ & $* *$ \\
\hline Isoleucine & $4.97 \pm 0.02(3)$ & $4.99 \pm 0.02$ & $3.84 \pm 0.06$ & $5.98 \pm 0.22$ & - \\
\hline Leucine & $8.18 \pm 0.10$ & $8 \cdot 23 \pm 0.10$ & $6.36 \pm 0.04$ & $10.02 \pm 0.08$ & 一 \\
\hline Tyrosine & $3.82 \pm 0.04$ & $3.60 \pm 0.14$ & $2.80 \pm 0.16$ & $6.62 \pm 0.24$ & $*$ \\
\hline Phenylalanine & $4 \cdot 32 \pm 0.22$ & $4.46 \pm 0.20$ & $3.74 \pm 0.14$ & $6.00 \pm 0.12$ & - \\
\hline Hydroxylysine & 二 & - & $0.54 \pm 0.03$ (2) & 二 & - \\
\hline Lysine & $9.79 \pm 0.19(6)$ & $8.72 \pm 0.18(8)$ & $6.88 \pm 0.16$ & $8.85 \pm 0.22$ & $* * *$ \\
\hline Histidine & $2.72 \pm 0.10$ & $2.40 \pm 0.02$ & $2.07 \pm 0.10$ & $3.46 \pm 0.12$ & $* * *$ \\
\hline Arginine & $6 \cdot 76 \pm 0.66$ & $6.59 \pm 0.18$ & $7 \cdot 12 \pm 0.28$ & $4 \cdot 13 \pm 0.14$ & 一 \\
\hline Cystine & $1 \cdot 23 \pm 0.02$ & $0.44 \pm 0.02(5)$ & $0.83 \pm 0.04$ & $0.44 \pm 0.06$ & $* * *$ \\
\hline Hydroxyproline & - & - & $2.95 \pm 0.05(6)$ & - & 一 \\
\hline Ammonia & $1.59 \pm 0.02$ & $1 \cdot 99 \pm 0.06$ & $1.52 \pm 0.04$ & $2 \cdot 18 \pm 0.08$ & **** \\
\hline Nitrogen $(\mathrm{g} / \mathrm{l} 00 \mathrm{~g})$ & $13 \cdot 5$ & I3.8 & $9 \cdot 9$ & $13 \cdot 4$ & - \\
\hline $\operatorname{Ash}(g / 100 \mathrm{~g})$ & $5 \cdot 16$ & $5 \cdot 57$ & $22 \cdot 53$ & 一 & - \\
\hline g N/g ash & $2 \cdot 61$ & $2 \cdot 48$ & 0.44 & 一 & - \\
\hline $\begin{array}{l}\% \mathrm{~N} \text { recovered as } \\
\text { amino acids }+ \\
\text { ammonia }\end{array}$ & $94^{\circ} \mathrm{I}$ & $94^{\circ} 6$ & $97 \cdot 2$ & $102 \cdot 6$ & - \\
\hline $\begin{array}{l}\% \mathrm{~N} \text { recovered as } \\
\text { ammonia }\end{array}$ & $7 \cdot 3$ & $9 \cdot 9$ & $7 \cdot 2$ & 10.9 & 一 \\
\hline
\end{tabular}

*P<0.05; ** $P<0.01 ; \quad * * * P<0.001$.

$\uparrow$ The standard error of each mean may be derived by dividing the given standard deviation by $\sqrt{ } \boldsymbol{n}$. where $n$ is the number of individual estimations on which the mean is based.

To avoid doubly recording the cystine nitrogen, the total ammonia nitrogen determined was corrected by an amount equivalent to the cysteic acid found. Amino acids and ammonia in the hydrolysates accounted for $94 \cdot 1,94 \cdot 6,97 \cdot 2$ and $102 \cdot 6 \%$ of the nitrogen in the control cod fillets, heated cod fillets, white-fish meal and casein respectively.

In a comparison between the control cod fillets and the heated cod fillets several differences reached statistical significance. The heat treatment had the effect of reducing concentrations of cystine, histidine, taurine, lysine, serine and threonine in 
descending order of magnitude of their percentage loss. The ammonia content of hydrolysates prepared from heated cod fillets was significantly higher than that with the control cod fillets. Both methionine and alanine were found in slightly, but significantly, greater concentrations in the heated cod fillets. The difference in the nitrogen:ash ratios between heated and unheated cod muscle indicated that heating had caused a $5 \%$ loss of nitrogen.

\section{DISCUSSION}

Differences in the origin and preparation of the materials analysed limit a strict comparison of our values with those given in the literature for similar materials. Whereas our cod meals were freeze-dried without preliminary extraction, Connel \& Howgate (1959) extracted with ethanol and ethyl ether before air drying. Their analysis, also done by ion-exchange chromatography, gave higher values for threonine, serine, alanine, leucine, histidine and cystine. Only their methionine value was very much lower. There were no consistent differences between the results obtained by chromatographic methods and the results of Braekkan \& Boge (I962) obtained by microbiological assay of cod muscle which had undergone a preliminary acetone extraction. The amino acid compositions of white-fish meals may be expected to cover a wide range of values according to the nature of the raw material. The raw materials may range from whole fish to offal meals containing everything except the fillets of muscle. Even offal meal may contain varying proportions of skin, bone and flaps. White-fish meal containing some muscle could be expected to have an amino acid composition intermediate between that of the all-offal meal presented here and of the cod muscle, i.e. less serine, proline, glycine and alanine and more valine, methionine, isoleucine, leucine, tyrosine, lysine, histidine and cystine. The range of hydroxyproline reaches zero for the cod muscle. Results of Agren's (195I) microbiological assay of a fish meal made mainly from cod and cod scraps and extracted with ethyl ether reflect a trend in accordance with a higher muscle content in the Norwegian meal. But the magnitude of differences for the different amino acids is not consistent. The composition of casein was found to be in good agreement with other values quoted in the literature (Rutgers University: Bureau of Biological Research, I95०; Grassmann, Hannig \& Plöckl, r955). Both casein and white-fish meal are used as standard proteins in the nutritional evaluation of protein quality, yet their content of essential amino acids in terms of total nitrogen differs appreciably. Observations with one standard will not necessarily allow deductions to be made for the other. White-fish meal contains $20-40 \%$ less of the individual essential amino acids than casein with the exception of cystine + methionine and of arginine. Cystine + methionine contents are similar in both. The arginine content is $75 \%$ higher in white-fish meal than in casein so that the overall values for nitrogen derived from the essential amino acids for casein of $43 \%$ and for white-fish meal of $49 \%$ are similar. Heat treatment of the moistened cod muscle at $105^{\circ}$ for $36 \mathrm{~h}$ caused statistically significant losses of serine $(8 \%)$, tyrosine $(6 \%)$, lysine ( 1 I \%), histidine (12\%) and cystine $(64 \%)$. E. L. Miller, A. W. Hartley \& D. C. Thomas (1965, private communication) observed similar losses of cystine and lysine when heating cod muscle. A heat treatment which 
reduced the available lysine content of an unspecified white-fish meal to $66 \%$ (Mason \& Weidner 1964) as against our $62 \%$ appears to have caused similar destruction of amino acids. Losses of cystine were the highest, and methionine was amongst the most stable acids. Only tyrosine behaved markedly differently. Heating caused a small increase in tyrosine content. In spontaneously heated whole-herring meal the principal losses were found in lysine, histidine and cystine (Boge, 1960). McDermott \& Pace (1957) demonstrated a similar effect when heating protein in the presence of a large excess of starch. During the baking of bread, the principal amino acids lost from the crust were serine $(8 \%)$, valine $(8 \%)$, tyrosine $(17 \%)$, phenylalanine $(16 \%)$ and lysine (13\%). Cystine content of the crust was not estimated. The losses of serine and lysine were very similar in cod muscle and in bread crust but losses of tyrosine were much larger in the latter.

A small but statistically significant increase of the alanine and methionine contents was observed when cod muscle was heated. It is possible that slight destruction of amino acids is more general than these results indicate. Apart from the higher ammonia level in hydrolysates prepared from heated cod muscle, the fall of the nitrogen: ash ratio after heating reflects an overall loss of nitrogen of about $5 \%$. Were methionine and alanine the most heat-stable amino acids under these conditions, just such an increase in their concentration relative to total nitrogen could be expected.

Whereas heating of the cod muscle reduced total lysine by $\mathrm{I} \cdot \mathrm{I} \mathrm{g} / \mathrm{I} 6 \mathrm{~g}$ nitrogen, available lysine was reduced by $3.0 \mathrm{~g} / \mathrm{I} 6 \mathrm{~g}$ nitrogen (Carpenter et al. 1957 ). The recovery of $63 \%$ of the lysine made unavailable by heating when hydrolysing in $6 \mathrm{~N}$-hydrochloric acid is in good agreement with the $67 \%$ recovery of lysine from milk powder observed by Mauron, Mottu, Bujard \& Egli (1955) and 70\% recovery from a mixture of casein and glucose, by Lea \& Hannan (1950).

\section{SUMMARY}

I. The amino acid composition of a vacuum-dried sample of cod muscle, the same material heated under controlled conditions, a cod-offal meal and of casein was estimated by Moore \& Stein ion-exchange chromatography.

2. The recovery of nitrogen determined by the Kjeldahl method as amino acid nitrogen and ammonia amounted to $94,95,97$ and 103\% respectively.

3. Under the heat treatment lysine, histidine and cystine suffered most destruction while alanine and methionine appeared to be the most stable.

4. The results are discussed in relation to similar values quoted in the literature.

\section{REFERENCES}

Agren, G. (1951). Acta chem. scand. 5, 766.

Association of Official Agricultural Chemists (1950). Official and Tentative Methods of Analysis, $7^{\text {th }}$ ed. Washington, DC: Association of Official Agricultural Chemists.

Boge, G. (1960). F. Sci. Fd Agric. II, 362.

Braekkan, O. R. \& Boge, G. (1962). FiskDir. Skr. Serie Teknologiske undersøkelser, 4, no. 3.

Carpenter, K. J., Ellinger, G. M., Munro, M. I. \& Rolfe, E. J. (1957). Br. F. Nutr. Iт, г6z.

Connell, J. J. \& Howgate, P. F. (1959). F. Sci. Fd Agric. Io, 241.

Eastoe, J. (I955). Biochem. F. 6r, 601.

Grassmann, W., Hannig, K. \& Plöck1, M. (1955). Hoppe-Seyler's Z. physiol. Chem. 299, 258. 
Heiman, V., Carrer, J. S. \& Cook, J. W. (1939). Poult. Sci. 18, 464.

Lea, C. H. \& Hannan, R. S. (1950). Biochim. biophys. Acta, 5, 433.

McDermott, E. E. \& Pace, J. (I957). Br. F. Nutr. I1, 446.

Mason, V. C. \& Weidner, K. (1964). Acta Agric. scand. 14, 87.

Mauron, J., Mottu, F., Bujard, E. \& Egli, R. H. (1955). Archs Biochem. Biophys. 59, 433.

Moore, S., Spackman, D. H. \& Stein, W. H. (1958). Analyt. Chem. 30, I 85.

Moore, S. \& Stein, W. H. (1954). F. biol. Chem. $211,907$.

Neuman, R. E. \& Logan, M. A. (1950). F. biol. Chem. 184, 299.

Rutgers University: Bureau of Biological Research (1950). Cooperative Determinations of the Amino Acid Content, and of the Nutritive Value of Six Selected Protein Food Sources. New Brunswick, N.J.: Rutgers University Press.

Schram, E., Dustin, J. P., Moore, S. \& Bigwood, E. J. (1953). Analytica chim. Acta, 9, 149.

Schram, E., Moore, S. \& Bigwood, E. J. (1954). Biochem. F. 57, 53. 